Review

\title{
SEAWEEDS IN VITICULTURE: A REVIEW FOCUSED ON GRAPE QUALITY
}

\section{ALGAS MARINHAS NA VITICULTURA: UMA REVISÃO FOCADA NA QUALIDADE DA UVA}

\author{
Gastón Gutiérrez-Gamboa, Yerko Moreno-Simunovic* \\ Centro Tecnológico de la Vid y el Vino, Facultad de Ciencias Agrarias, Universidad de Talca, 2 Norte 685, Casilla 747, 346000, Talca, \\ Chile. \\ * Corresponding author: Tel.: +56 712201556, e-mail: ymoreno@utalca.cl
}

(Received 22.11.2020. Accepted 08.03.2021)

\section{SUMMARY}

Cell walls of seaweeds contain a wide number of organic and inorganic constituents, of which polysaccharides have important biological activity. Some researchers suggest that polysaccharides from seaweeds can behave as biotic elicitors in viticulture, triggering the synthesis of phenolic compounds in leaves and grape berries. The mechanism of action of seaweeds after a foliar application to grapevines is not fully understood but it is discussed in this review. An overview of the recent research focused on the effects of seaweeds foliar applications on grapevine productivity, on grape and wine quality is included as well as a short-term future perspective for the research in this field.

\section{RESUMO}

As paredes celulares das algas marinhas contêm um elevado número de constituintes orgânicos e inorgânicos, dos quais os polissacáridos têm importante atividade biológica. Alguns investigadores sugerem que os polissacáridos de algas marinhas podem comportar-se como elicitadores bióticos em viticultura, desencadeando a síntese de compostos fenólicos em folhas e uvas. Os mecanismos de ação após a aplicação foliar de algas marinhas em videiras não foram totalmente estudados, mas são discutidos nesta revisão. É incluída uma visão geral dos trabalhos de investigação recentes sobre os efeitos das algas marinhas aplicadas, por via foliar, na produtividade da vinha, na qualidade da uva e do vinho, assim como uma perspetiva de estudo futuro de curto prazo para a investigação neste campo.

Key words: amino acids, seaweeds, polysaccharides, elicitation, foliar fertilizer, phenolic compounds, volatile compounds.

Palavras-chave: aminoácidos, algas marinhas, polissacáridos, elicitação, fertilizante foliar, compostos fenólicos, compostos voláteis.

\section{INTRODUCTION}

Intensive food production for human and animal consumption, based on conventional agricultural systems, can lead to the indiscriminate use of agrochemicals, generating a negative effect on the conservation of biodiversity worldwide (Hannah et al., 2013; Provost and Pedneault, 2016; Adhikari et al., 2019; Banerjee et al., 2019; Gutiérrez-Gamboa et al., 2019a; Neset et al., 2019). These negative impacts include greater contamination of soils that decrease their fertility, as well as water pollution (Parris, 2011). On the other hand, and during the past decades, there has been a massive increase in marine eutrophication globally (Howarth, 2008), mainly driven by an excess of nitrogen and phosphorus coming from anthropogenic activities that can leach into groundwater or move into waterways via surface runoff (Parris, 2011; Ngatia et al., 2019). Eutrophication leads to an excessive algae production, blooms of harmful algae, including an increase of the frequency of anoxic events, and the death of several fish species (Ngatia et al., 2019). These conditions lead to economic losses for fish and oyster producers, including losses of recreational amenities, such as beaches and lakes (Ngatia et al., 2019).

Crop fertilization using seaweeds dates back to ancient times. However, the development of agrochemicals at the end of the $19^{\text {th }}$ century made the use of natural and organic products less popular (Craigie, 2011). Due to the aforementioned problems and the current global situation in relation to the demand for organic fertilizers in developed countries, an opportunity for the use of algae in viticulture has been opened, as they have been widely used in other horticultural crops with the aim to improve quality and disease resistance (Battacharyya et al., 2015). Based on this, the

This is an Open Access article distributed under the terms of the Creative Commons Attribution License (https://creativecommons.org/licenses/by/4.0), which permits unrestricted use, distribution, and reproduction in any medium, provided the original work is properly cited. 
utilization of algae in viticulture is currently under study and there are few reports in the literature assessing its effect on avoiding grapevine diseases and improving grape and wine quality (Aziz et al., 2003; Sharma et al., 2014; Zhang et al., 2016; Frioni et al., 2018, 2019; Mondello et al., 2018; Gutiérrez-Gamboa et al., 2019b; Salvi et al., 2019; Taskos et al., 2019; Gutiérrez-Gamboa, 2020; Gutiérrez-Gamboa et al., 2020a,b,c; Thankaraj et al., 2020).

Seaweed extracts contain several substances that promote plant growth, such as auxins, cytokinins, betaines and gibberellins, as well as organic substances, such as amino acids, macronutrients and trace elements, which can improve crop yield and quality (Khan et al., 2009; Craigie, 2011; Arioli et al., 2015; Battacharyya et al., 2015). Therefore, the aim of this work was to revise recent research that has evaluated the effects of seaweed extracts on grapevine productivity and grape and wine quality, and to propose a short-term future perspective for the research in this field.

\section{SPECIES OF ALGAE USED AS EXTRACTS AND THEIR COMPOSITION}

Seaweeds are a diverse group of photosynthetic eukaryotic organisms that cover about 10,000 species of red, brown and green algae (Khan et al., 2009). Respect to their abundance and distribution, brown algae (Phaeophyceae) are the most used for commercial extract preparation with several applications in horticulture (Battacharyya et al., 2015). Most of the biostimulant products elaborated from algae are manufactured from a single species of brown algae (Ascophyllum nodosum), which is abundantly distributed along the Northwest coast of Europe and the Northeast coast of North America (Craigie, 2011). However, several commercial extracts currently available in the markets are made from other species of brown algae, such as Ecklonia maxima, Durvillaea potatorum, D. antarctica, Himanthalia elongata, Laminaria digitata, $L$. hyperborea, Macrocystis pyrifera, and Sargassum spp., although other minor species, such as Fucus serratus, Ulva intestinalis, $U$. lactuca and Kappaphycus alvarezii are also used (Craigie, 2011; Sharma et al., 2014; Gutiérrez-Gamboa, 2020).

Commercial extracts made from brown algae (Ascophyllum nodosum) contain a wide range of inorganic and organic components (Verkleij, 1992; Sharma et al., 2014) including nitrogen, phosphorus, potassium, calcium, iron, magnesium, zinc, sodium and sulfur (Fleurence, 2004; Rayirath et al., 2009). Brown algae extracts also contain varying amounts of amino acids (Fleurence, 2004; Rayirath et al., 2009; Blunden et al., 2010; MacKinnon et al., 2010; Gutiérrez-Gamboa et al., 2020c) and only between 3 to $15 \%$ of their dry weight in proteins, representing a lower content than that found in green and red algae, which varies from 10 to $47 \%$ of their dry weight (Fleurence, 1999, 2004; Nagahama et al., 2009; Sharma et al., 2014; Gutiérrez-Gamboa, 2020).

Polysaccharides are one of the main components of commercial extracts of most algae species (Sharma et al., 2014). These components can represent up to 30 or $40 \%$ of the dry weight of the seaweed extract (Rayirath et al., 2009). In the case of brown algae extracts, the most common polysaccharides are alginates, fucoidans, laminates and glucans (Khan et al., 2009). Fucoidans have different molecular structure according to their varying degrees of methylation, sulfation and branching (Battacharyya et al., 2015). Depending on the chemical and physical methods used during raw material extraction, harvest season and species of algae, the structure of fucose-containing polymers varies (Craigie, 2011). Similarly, alginates that are polymers of D-mannuronic and L-guluronic acids that have been shown to promote plant growth (Yabur et al., 2007), vary in viscosity according to the species of algae used (Battacharyya et al., 2015). Other important components of seaweed extracts are laminarins, well known elicitors that are used in viticulture and that have an effect in modulating the defense responses of plants against fungal and bacterial pathogens (Mercier et al., 2001; Aziz et al., 2003; Gauthier et al., 2014; Nesler et al., 2015; Romanazzi et al., 2016; GardeCerdán et al., 2017; Lemaître-Guillier et al., 2017).

Brown algae, especially Ecklonia stolonifera, Fucus vesiculosus, F. serratus and Ascophyllum nodosum can reach high concentrations of phenolic compounds even up to $30 \mathrm{~g} / 100 \mathrm{~g}$ of extract (Audibert et al., 2010; Keyrouz et al., 2011; Balboa et al., 2013; Battacharyya et al., 2015). Phenolic compounds play a primary role in the structural components of algae cell walls protecting cells and their components (Nakamura et al., 1996; Wang et al., 2009). Phlorotannins are oligomers of phloroglucinol existing in brown algae have been found to be more efficient antioxidants compared to catechin, ascorbic acid, epigallocatechin gallate, resveratrol and tocopherol (Shibata et al., 2003).

Seaweed extracts also contain several phytohormones, including auxins, cytokinins, gibberellins, abscisic acid and brassinosteroids (Stirk and Van Staden, 1996; Stirk et al., 2004; Stirk et al., 2014; Battacharyya et al., 2015; Gutiérrez-Gamboa, 2020). Brown algae such as Alaria esculenta, Ascophyllum nodosum, Ectocarpus siliculosus, Fucus serratus, F. spiralis, F. vesiculosus, Halidrys siliquosa, Laminaria digitata, L. hyperborea, L. saccharina and Pilayella littoralis contain osmolytes such as mannitol, an important protective compound that is activated in response to abiotic factors (Battacharyya et al., 
2015; Gutiérrez-Gamboa, 2020). Mannitol is also known as a chelating agent, which explains why algae can release otherwise unavailable elements from the soil for plant crop use (Reed et al., 1985). Additionally, considerable amounts of melatonin have been documented in the brown algae Pterygophora californica (Fries and ThorénTolling, 1978).

One of the unique characteristics of Ascophyllum nodosum is its mutualistic association with the fungal endophyte Mycosphaerella ascophylli (Fries and Thorén-Tolling, 1978; Fries, 1979; Garbary and Gautam, 1989; Craigie, 2011; Shukla et al., 2019) that protects $A$. nodosum from desiccation (Garbary and Gautam, 1989). Interestingly, it has been showed that fungal sterols derived from $M$. ascophylli present in extracts made from $A$. nodosum can mitigate salinity stress in plants (Shukla et al., 2019).

\section{PROCEDURES FOR SEAWEED BIOSTIMULANT PRODUCTION}

Seaweed composition provides an excellent opportunity for the biostimulant industry (Godlewska et al., 2016). Extraction is the most important and starting step in isolating different types of components that condition seaweed extract bioactivity (Jeong et al., 2004; Godlewska et al., 2016; Shukla et al., 2019). Extraction efficiency is mostly reduced by the presence of algae cell walls, which can be affected by solvent composition, temperature, time, and $\mathrm{pH}$ (Godlewska et al., 2016). Different extraction techniques have been used to maximize biologically active compounds from seaweeds such as acid and alkaline hydrolysis, microwave assisted extraction, supercritical fluid extraction, pressurized liquid extraction, Soxhlet extraction, enzyme-assisted extraction (EAE), and ultrasound-assisted extraction (UAE) (Godlewska et al., 2016; Shukla et al., 2019). These extraction techniques use different solvents such as ethanol, acetone, methanol-toluene, methanol, petroleum ether, ethyl acetate, dichloromethane, and butanol (Ganesan et al., 2008; Godlewska et al., 2016). Some of abovementioned techniques require the use of expensive and toxic solvents, nevertheless simpler procedures such as seaweed boiling and soaking as methods for obtaining extracts have been successfully developed (Godlewska et al., 2016).

In water based extractions, raw materials are washed with fresh water to remove sand, stones and other debris, later chopped and oven dried at a temperature lower to $80{ }^{\circ} \mathrm{C}$ (Sharma et al., 2014). The solid residues are then separated using different filtration methods based on the end use of the biostimulant to be produced (Shukla et al., 2019). This process has several advantages over the normal extraction procedure in terms of acid, alkali, and enzymatic reaction (Saravana et al., 2018). Biostimulants obtained through water or acid hydrolysis are reported to be rich in phytohormonelike activity (Blunden et al., 2010; Shukla et al., 2019). The main advantages of this technique is that only water is used as an extraction solvent, it is environmentally friendly and it does not require organic solvent (Godlewska et al., 2016; Saravana et al., 2018).

In acid hydrolysis extractions, seaweed biomass is treated with sulfuric or hydrochloric acid under temperature conditions $\left(40\right.$ to $\left.50{ }^{\circ} \mathrm{C}\right)$ over a period of time (30 min, approximately) (Shukla et al., 2019). This process is usually used for the extraction of fucose-containing sulfated polysaccharides and also may include calcium addition to promote alginate precipitation during purification (Chizhov et al., 1999; Ale et al., 2012). The process of acid hydrolysis induces a remotion of complex phenolic compounds but an increase in the de-polymerization of polysaccharides (FlórezFernández et al., 2018).

Most commercial biostimulants produced from brown algae are produced by alkaline hydrolysis (Craigie, 2011; Briceño-Domínguez et al., 2014). This method involves extracting seaweeds in sodium or potassium hydroxide solutions at temperatures less than $100^{\circ} \mathrm{C}$ (Shukla et al., 2019). Seaweed viscosity produced from Macrocystis pyrifera increases with increasing $\mathrm{pH}$ and temperature to a maximum which occurs at $\mathrm{pH} 10$ and $80{ }^{\circ} \mathrm{C}$ (Briceño-Domínguez et al., 2014). Alkaline hydrolysis also breaks down complex polysaccharides into smaller, lower-molecularweight oligomers (Shukla et al., 2019). Some water-soluble fractions and certain oligo and polysaccharides of importance could be lost (Sharma et al., 2014), and new compounds not initially present in the algae biomass could be formed (El Boukhari et al., 2020). Therefore, further separation and purification steps are necessary to maximize the extraction yield (Sharma et al., 2014).

UAE appears as an interesting alternative to solve the problems mentioned above (El Boukhari et al., 2020). UAE has allowed to optimize the extraction time of carrageenans and alginates from different seaweed species, without altering their chemical structure and molar mass distribution (Kadam et al., 2015a; Youssouf et al., 2017; El Boukhari et al., 2020). In this way, extraction yields of $143.12 \mathrm{mg}$ $\mathrm{GAE} / \mathrm{g}_{\mathrm{db}}, 87.06 \mathrm{mg} / \mathrm{g}_{\mathrm{db}}$ and $128.54 \mathrm{mg} / \mathrm{g}_{\mathrm{db}}$ were obtained for total phenolics, fucose and uronic acid respectively at optimized extraction conditions of extraction time $(25 \mathrm{~min})$, acid concentration $(0.03$ $\mathrm{M} \mathrm{HCl})$ and ultrasonic amplitude $(114 \mu \mathrm{m})$ (Kadam et al., 2015b). UAE technology may also enhance the extraction of high molecular weight phenolic compounds from brown seaweeds (Kadam et al., 
2015a). Despite these improvements, the level of variability of extraction methodologies is still significant as to respond to industrial requirements (El Boukhari et al., 2020).

EAE is a promising biotechnological application that has been widely used to improve the extraction efficiency of bioactive components (Sabeena et al., 2020). EAE increases yield, high specificity, and preserves protein properties and it is a fast, scalable, and environmentally friendly method (El Boukhari et al., 2020; Sabeena et al., 2020). Protein extraction yield can be maximized by the optimization of certain physicochemical parameters such as hydrolysis time, $\mathrm{pH}$, and temperature (Vásquez et al., 2019; El Boukhari et al., 2020). Enzymatic extracts obtained by hydrolyzing seaweeds with different carbohydrases and proteases presented significant antioxidant and antimicrobial activity (Sabeena et al., 2020). However, some published reports show excessive extraction time and low yields compared to the extracts obtained from conventional methods using chemicals (Okolie et al., 2019; Vásquez et al., 2019).

It is important to note that when trying to extract a wide number of bioactive compounds, several interactions may occur within the mixture leading to both synergistic and antagonistic effects (El Boukhari et al., 2020). For this reason, seaweed extraction techniques should be performed always considering biomass features, biostimulant's mode of application, crop's type, and the desired physiological effect such as abiotic stress tolerance, improvement of soil fertility or enhancement of fruit quality.

\section{PHYSIOLOGICAL ASPECTS OF SEAWEED FOLIAR APPLICATIONS}

Plant tissue interactions after seaweed
applications

Through evolution plants have developed passive and active mechanisms to defend themselves against pathogens (Saigne-Soulard et al., 2015). Passive mechanisms, such as structural barriers and antifungal compounds contribute to delay disease development (Saigne-Soulard et al., 2015). Similarly, plants produce a wide number of secondary metabolites, such as terpenes, steroids, phenolics, pathogenesis-related (PR) proteins and alkaloids, developing active defense mechanisms, which play a key role in plant defense and adaptation to the environment (Ramirez-Estrada et al., 2016). These mechanisms are induced only if the plants recognize the pathogen by the perception of signal molecules called elicitors (Delaunois et al., 2014; Saigne-Soulard et al., 2015). Elicitors comprise a wide range of abiotic and biotic components (Delaunois et al., 2014). Abiotic elicitors can be physical stimuli or chemical compounds, while biotic elicitors usually refer to molecules secreted by microorganisms, derived from cell walls of fungi, bacteria and host plants or from seaweeds (Saigne-Soulard et al., 2015). Rgenes (resistance genes) convey disease resistance against pathogens in plants by producing leucinerich proteins ( $\mathrm{R}$ proteins) (Liu et al., 2017). These genes may be involved in elicitor binding and pathogen recognition and could initiate signaling pathways that activate various defenses against pathogens (Marone et al., 2013). Once the elicitor is recognized by the R-gene complex, signaling pathways are initiated resulting in the activation of defense responses (Malik et al., 2020). A transient change in permeability is generated in the plasma membrane, stimulating the inflow of $\mathrm{Ca}^{2}+$ and $\mathrm{H}^{+}$ ions into the cells and an outflow of $\mathrm{K}^{+}$and $\mathrm{Cl}^{-}$ ions, which leads to an extracellular alkanization and a depolarization of the plasma membrane (Bigeard et al., 2015). This activates the oxidative response of the plant and the signaling of other defense reactions (Malik et al., 2020). These reactions are essential to initiate the signaling network that will activate all plant defense responses (Hammond-Kosack and Jones, 1996; Malik et al., 2020).

Seaweeds contain bioactive substances such as polysaccharides, proteins, lipids, and polyphenols with a diversity of antibacterial, antiviral, and antifungal activity (Peso-Echarri et al., 2012). Cell walls of seaweeds contain a wide range of polysaccharides, such as $\beta$-(1 $\rightarrow 3)$-glucans that are formed by neutral sugars and acids, and can act as elicitors when applied to plant tissues (Battacharyya et al., 2015). Preliminary studies reported that a linear $\quad \beta-(1 \rightarrow 3)$-glucans applied to tobacco (Nicotiana tabacum) induced immunity through a series of reactions, such as the production of Reactive Oxygen Species (ROS), the expression of defense genes, a strong enzymatic activity of phenylalanine ammonia lyase, caffeic acid $O$ methyltransferase and lipoxygenase, and the accumulation of salicylic acid and PR proteins of family 1, 2, 3 and 5 in the leaves (Klarzynski et al., 2000; Ménard et al., 2004). Aziz et al. (2003) showed that a laminarin extract from Laminaria digitata applied to grapevine leaves reduced infection by Botrytis cinerea and Plasmopara viticola in greenhouse trials. The authors explained this effect based on extract implications on the calcium influx, alkalinization of the extracellular medium, production of ROS, expression of defense genes and the accumulation of stilbene phytoalexins, such as resveratrol and viniferin. The accumulation of stilbenes has been recently confirmed in a field trial carried out after the application of an Ascophyllum nodosum extract on the 'Tempranillo Blanco' variety (GutiérrezGamboa, 2020). In addition, Garde-Cerdán et al. (2017) reported that a treatment based on laminarin 
and Saccharomyces extracts applied to grapevines decreased the content of several amino acids in grape berries. Probably, the induction of defense mechanisms in plants through exogenous elicitation may result in a physiological cost that involves the consumption of some amino acids as enzymatic substrates or the compartmentalization of these compounds in reserve organs as a survival mechanism (Gutiérrez-Gamboa et al., 2017a). Pathogenic microorganisms and seaweeds present a close structural similarity regarding their $\beta$ - $(1 \rightarrow 3)$ glucan composition that allows to induce plant defense mechanisms (Paris et al., 2019). A recent study showed that the elicitation of defense mechanisms against $P$. viticola in 'Marselan' grapevines using a laminarin extract was more associated to the direct antimicrobial activity related to the degree of acylation of the solution than to the elicitation performed by the bioactive compounds of the extract (Paris et al., 2019). The hydrophobic balance of seaweed bioactive compounds and its toxicity against plant diseases is addressed through partial masking of hydroxyl functions by acylation with long chain aliphatic groups (Paris et al., 2019). Nevertheless, the introduction of aliphatic groups can result in better interactions with the lipophilic cuticle and surfactant used as formulating agent, thus favoring penetration of the bioactive carbohydrate into plant leaves, and then increasing its bioavailability (Paris et al., 2019). Based upon these findings, it is important to develop optimized seaweed formulations with appropriate dosages and properties to improve their solubilization and their retention on the leaf surface for better effectiveness of the seaweed elicitor treatments. As was explained in this section, plants develop acquired systemic resistance (SAR) in subsequent pathogen attacks when they have previously survived to a pathogen affection and can develop a medium-long term protection against a wide range of pathogenic species (Malik et al., 2020). Therefore, continued exogenous application of the same elicitor throughout the growing season to induce the activation of defense mechanisms in plants may result in a certain degree of tolerance but it could not generate the same effects when a single application is used, particularly at the beginning of the season.

\section{Uptake of macro and micro elements by grapevine leaves}

Inorganic components of seaweed extracts may enter the plant through the leaves and stuck to reserve organs (Gutiérrez-Gamboa et al., 2020c). The processes by which a nutrient solution applied to the leaves is assimilated by plants include contact, leaf adsorption, cuticular or stomatal penetration, uptake and absorption into metabolically active cell compartments in the leaf, and finally, the translocation and utilization of the nutrients absorbed by the plant (Fernández et al., 2013). Nutrient absorption by plant surfaces occurs via cuticle, cuticular stacks and imperfections, stomata, trichomes and lenticels (Fernández et al., 2013). Epidermal structures such as stomata and lenticels are permeable to foliar fertilizer solutions, while lipophilic solutions may cross cuticles via a solution-diffusion process (Fernández et al., 2013). To enter the leaf, molecules must diffuse across an air boundary layer at the leaf surface or move from a region of high to low concentration with a magnitude that is proportional to the concentration gradient (Nobel, 2009; Fernández et al., 2013). This energy balance is dominated by the first Fick's Law of diffusion (Figure 1).

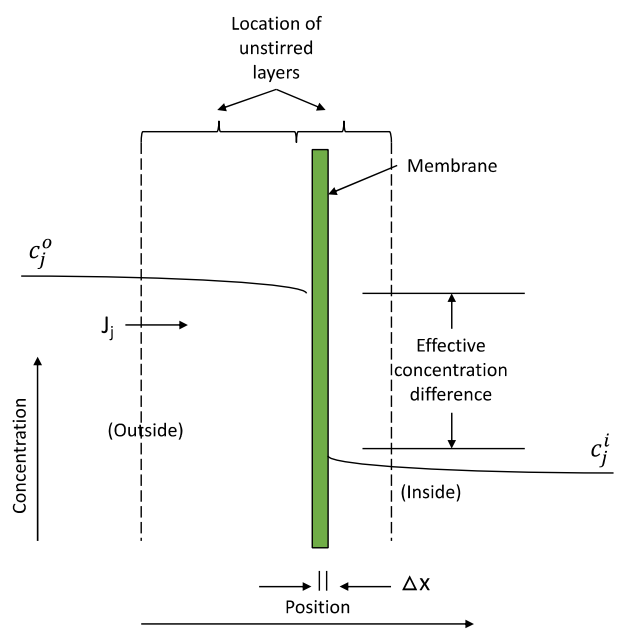

Figure 1. The effect of unstirred layers (dashed lines) on the concentration of species $\mathrm{j}$ near a membrane across which the solute is diffusing.

Stomata may represent the main pathway for $\mathrm{N}$ absorption since they do not present a waxy layer and its waxy cuticle has different degrees of polarity resulting in an efficacious $\mathrm{N}$ transmission compared to leaf cuticle (Norms and Bukovac, 1968; Leece, 1976; Cheng et al., 2020). Grapevines leaves have a greater number of stomata on their abaxial side than on the adaxial one (Rogiers et al., 2011). Therefore, grapevine is considered as a hypostomatic species and stomata density of its leaves varies greatly in response to soil temperature and atmospheric $\mathrm{CO}_{2}$ concentration (Rogiers et al., 2011). Nevertheless, the stomatal pathway contribution to the foliar uptake process should be further elucidated as well as the role of other epidermal structures such as trichomes and lenticels (Fernández et al., 2013). In this sense, a reinterpretation of the plant cuticle as a lipidized epidermal cell wall region and, consequently, its contribution to nutrient uptake has been recently proposed (Fernández et al., 2016). Some studies on the penetration of substances through the cuticles 
indicate that the process is only passive and not mediated by energy, since they are devoid of living cells (Fernández et al., 2016). Therefore, the cuticle should be considered as a composite material made of lipophilic components (apolar compounds) such as waxes and cutin, and hydrophilic components (polar compounds), such as polysaccharides (Fernández et al., 2016, 2017).

Ultrastructure and chemical features of the leaf render it difficult the wetting and the permeability of polar nutrient solution foliar applications (Fernández and Eichert, 2009). In this sense, erect and prostrate trichomes are the most characteristic features present on the epidermal surfaces of grapevine leaves (Konlechner and Sauer, 2016). Contact angles are hugely affected by these hairs, resulting in individual cases in values $>150^{\circ}$ (high hydrophobicity) in the presence of a high reclining of hair density (Konlechner and Sauer, 2016) (Figure 2). 'Grüner Veltliner', 'Welschriesling', 'Blauer Wildbacher' and 'Sauvignon Blanc' grapevine varieties presented remarkably hydrophobic abaxial leaves $\left(>140-152^{\circ}\right)$, while 'Pinot Noir' and 'Portugais Bleu' varieties, which present very low or absent hair growth, exhibited low hydrophobicity on both leaf sides (>95-105) (Konlechner and Sauer, 2016).

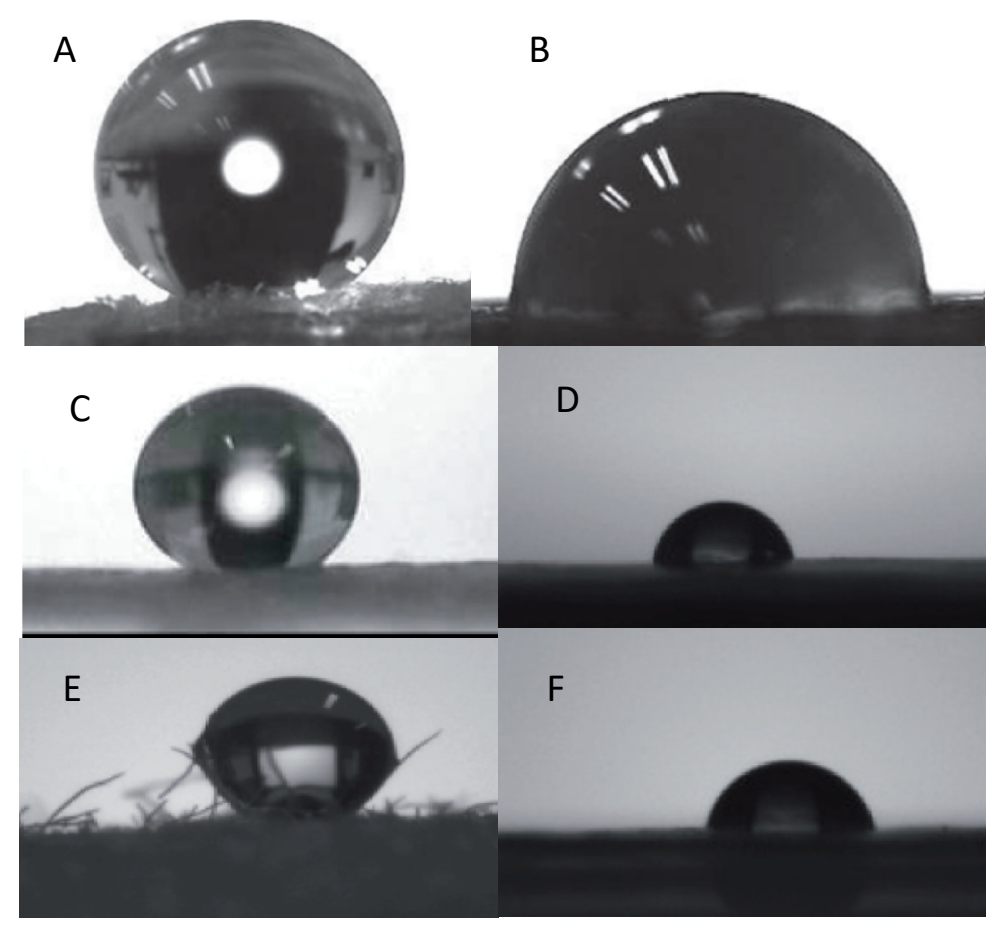

Figure 2. Contact angles with water drops of the abaxial surface of (A) 'Grüner Veltliner' (Vitis vinifera subsp. vinifera L.) leaf $\left(>152^{\circ}\right)$ and (B) adaxial side of 'Saint Laurent' (Vitis vinifera subsp. vinifera L.) leaf $\left(<90^{\circ}\right)$; (C) adaxial Eucalyptus globulus $\left(>140^{\circ}\right)$, and (D) Ficus elastica leaves $\left(>83^{\circ}\right)$; (E) Peach $\left(>130^{\circ}\right)$ and (F) Apple $\left(>84^{\circ}\right)$ fruit surfaces. Obtained from Konlechner and Sauer (2016), and Fernández et al. (2013).

The most important environmental factors that directly affect the uptake of nutrients by leaves are temperature and relative humidity (Fernández et al., 2013). High temperatures may increase the solute diffusion of the active ingredients and adjuvants, but may decrease solution viscosity, surface tension and the point of deliquescence (Ramsey et al., 2005; Fernández et al., 2013). Relative humidity may improve uptake efficacy by increasing cuticle hydration and delaying droplet drying (Ramsey et al., 2005). For these reasons, humectants are used successfully in warm and dry areas to increase uptake efficacy of the foliar applications (Ramsey et al., 2005). Thus, penetration of hydrophilic substances may be enhanced by hydration of the cuticle, while transcuticular transport of non-polar solutes is increased by factors which reduce wax viscosity (Kirkwood, 1999).

\section{SEAWEED BIOSTIMULATION VITICULTURE}

During the past two decades, world main winegrowing regions are facing unpredictable climatic conditions and a rise in temperature, mostly during the summer period, which have strongly affected grape ripening dynamics and quality (Jones and Davis, 2000; Tomasi et al., 2011; Keller, 2020). Seaweed-based biostimulants may provide vineyard protection against abiotic and biotic factors, improving grapevine productivity 
(Salvi et al., 2019) and play a key role in the development of environmentally friendly viticulture strategies, mitigating the negative effects of climate change (Sabir et al., 2014; Frioni et al., 2018). Most of the reports related to the effects of foliar application of seaweeds in viticulture have been focused on their impact in mitigating the negative effects of abiotic and biotic stress, grapevine productivity and grape berry physicochemical components (Table I), which are discussed in the following sections.

Table I

Selected recent scientific reports regarding the effects of different seaweeds foliar application in grapevine

\begin{tabular}{|c|c|c|}
\hline Reference & Algae & Effects \\
\hline Khan et al. (2012) & $\begin{array}{l}\text { Amino acid mixture }+ \\
\text { Ascophyllum nodosum }\end{array}$ & $\begin{array}{l}\text { Increased leaf size and chlorophyll content, cluster number per } \\
\text { shoot, stalk length, berry weight and soluble solids. }\end{array}$ \\
\hline Strydom (2014) & Biocel $+\mathrm{K}+$ leonardite & $\begin{array}{l}\text { Increased berry soluble solids, decreased total acidity and } \\
\text { anthocyanin content. }\end{array}$ \\
\hline Sabir et al. (2014) & A. nodosum & Did not affect the studied parameters. \\
\hline Sabir (2015) & Calcite $+A$. nodosum & Improved pollen viability. \\
\hline $\begin{array}{l}\text { Zermeño-González et al. } \\
\text { (2015) }\end{array}$ & Sargassum spp. & Increased $\mathrm{CO}_{2}$ assimilation rate, productivity and soluble solids. \\
\hline $\begin{array}{l}\text { Gutiérrez-Gamboa et al. } \\
\text { (2019) }\end{array}$ & A. nodosum + microelements & Increased fruit set and productivity in Carmenère grapevines. \\
\hline Frioni et al. $(2018,2019)$ & A. nodosum & $\begin{array}{l}\text { Increased anthocyanin accumulation in Sangiovese and Pinot } \\
\text { Noir, avoiding the affection of grapes by Botrytis cinerea. }\end{array}$ \\
\hline $\begin{array}{l}\text { Gutiérrez-Gamboa et al. } \\
(2017 \mathrm{~b}, \mathrm{c}, 2018)\end{array}$ & $\begin{array}{l}\text { Amino acid mixture }+ \text { Durvillaea } \\
\text { antarctica }\end{array}$ & $\begin{array}{l}\text { Increased amino acids content in grapes and the concentration } \\
\text { of higher alcohols and esters in wines. }\end{array}$ \\
\hline Salvi et al. (2019) & A. nodosum & $\begin{array}{l}\text { Increased gas exchange and avoided photoinhibition of leaves. } \\
\text { Delayed ripening and promoted the synthesis of phenolic } \\
\text { compounds in leaves and berries. }\end{array}$ \\
\hline Taskos et al. (2019) & A. nodosum $+\mathrm{N}$ to soil & $\begin{array}{l}\text { Increased the productivity and the anthocyanins extractability } \\
\text { from berry skins. }\end{array}$ \\
\hline
\end{tabular}

\section{Seaweed effects on grapevine productivity}

The application of a commercial extract of the seaweed Ascophyllum nodosum (ACADIAN®) at a dosage of $2.35 \mathrm{~L} /$ ha produced an increase in yield, cluster and berry weight, cluster size and firmness in 'Thompson Seedless' table grape variety, but had a negative effect on the accumulation of soluble solids in the berries (Norrie et al., 2002). Copper and other micronutrients absorption in one-year-old grapevines of the 'Karaerik' variety was improved after the application of three commercial extracts of seaweeds (Maxicrop ${ }^{\circledR}$, Proton $\AA$ and Algipower $($ ) at a dosage of 1.0 to $2.0 \mathrm{~g} / \mathrm{L}$ (Turan and Köse, 2004). Probably, seaweed extracts may increase membrane permeability of roots, leaves and stomata cells, enhancing copper uptake by plants (Verkleij, 1992). In another study, the foliar application to grapevines of an A. nodosum commercial extract (Alga Special ${ }^{\circledR}$ ) at a dose of $170 \mathrm{~mL} / \mathrm{hL}$ increased vegetative growth, shoot length and diameter and leaf area in 'Feteasca Alba' grapevine variety (Popescu and Popescu, 2014). A. nodosum brown alga is very effective at accumulating nutrients and minerals from the surrounding seawater and its harvested biomass is exploited as fertilizer in horticulture to improve physiological responses in plants when applied (Pereira et al., 2020). A soluble extract of $A$. nodosum applied foliarly to grapevines at a concentration of $0.5 \%(\mathrm{v} / \mathrm{v})$ increased leaf dry weight, berry weight and volume, and $\mathrm{Ca}, \mathrm{Zn}, \mathrm{S}, \mathrm{B}$ and chlorophyll leaf contents in 'Narince' grapevine variety (Sabir et al., 2014). Fruit set and productivity in 'Carmenère' grapevines cultivated under cold and warm climates was improved after the foliar application of a commercial $A$. nodosum extract (BM86®) at a dose of $3 \mathrm{~L} / \mathrm{ha}$ (GutiérrezGamboa et al., 2019b). Foliar application of a commercial fertilizer (Primo ${ }^{\circledR}$ ) elaborated based on an $A$. nodosum algae sprayed in multiple applications of $0.1 \mathrm{~mL} / \mathrm{L}$ increased leaf size and chlorophyll content, fruit set, number of clusters per shoot, rachis length, berry weight and size, soluble solids and $\mathrm{pH}$ values in musts, and reduced berry dehydration in 'Perlette' table grapevine variety (Khan et al., 2012). Despite the high effectiveness 
of seaweed foliar applications on productivity reported in the abovementioned works, some of these reports were limited to only one year of trials, living out of consideration that seasonal climate effects have an important influence in determining yield and their components in grapevines (Echeverría et al., 2017). Grapevine clusters that make up for the current season yield, began to differentiate the preceding growing season in the compound bud (Vasconcelos et al., 2009). Therefore, the maximum number of clusters per grapevine and by consequence, the potential grapevine yield, is determined in the previous season and it is not likely affected by seaweed applications performed in the current season.

\section{Seaweed effects on grape berry and wine composition}

Currently, there is little information available in the scientific literature addressing the effects of foliar applications of seaweeds to grapevines on the content of amino acids, volatile and polyphenol compounds in grapes and wines - Figure 3 (Frioni et al., 2019; Salvi et al., 2019; Taskos et al., 2019; Gutiérrez-Gamboa et al., 2020c).

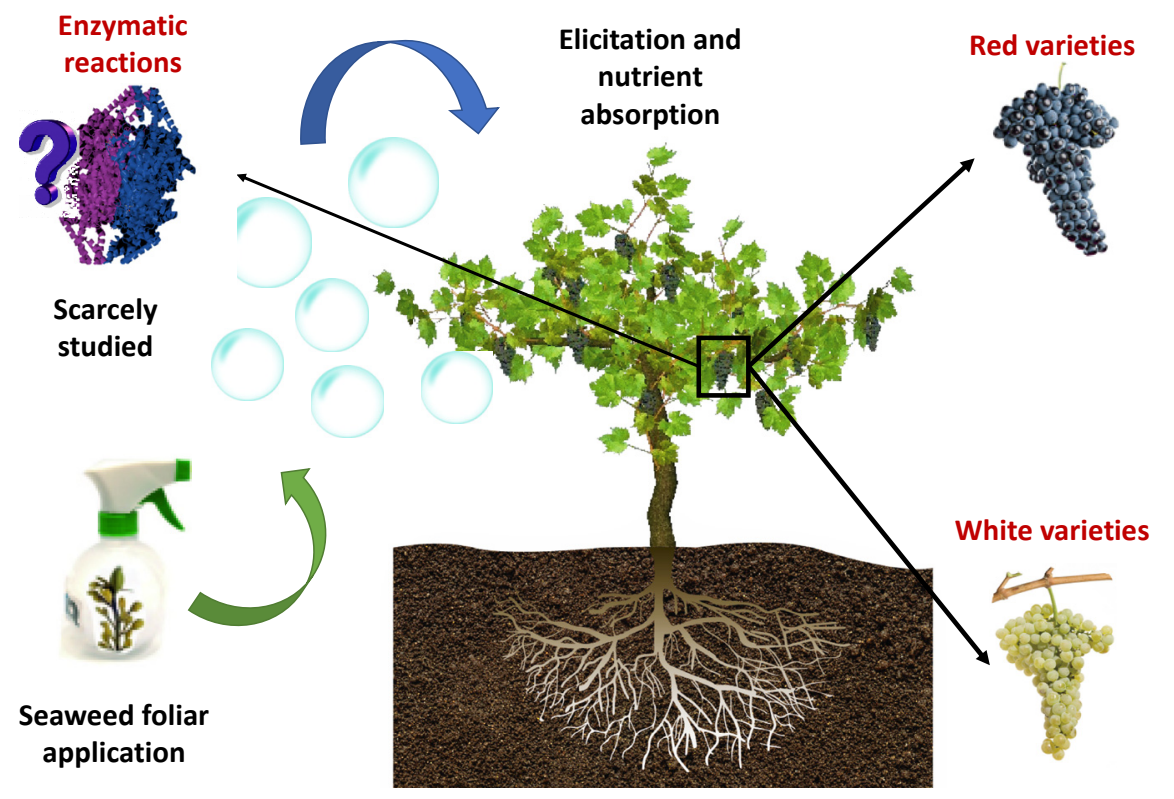

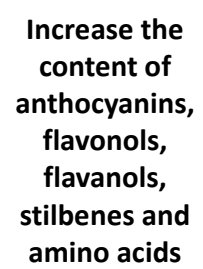

Increase the

content of

flavonols and

hydroxycinnamic acids

Figure 3. Summary of the effects of seaweeds foliar application to grapevines on grape composition.

A commercial nitrogen fertilizer (Basfoliar ${ }^{\circledR}$ Algae SL) based on the Durvillaea antartica algae applied to 'Cabernet Sauvignon' grapevines at $2 \mathrm{~kg} \mathrm{~N} / \mathrm{ha}$ in veraison increased the content of several amino acids in grapes and wines, which resulted in a higher content of some higher alcohols and ethyl esters in the elaborated wines, improving their fruity and floral aromas (Gutiérrez-Gamboa et al., 2017 b,c, 2018). Several works confirmed that the foliar application in the phenological state of veraison improves the nutrient absorption by grapevines compared to soil application (Lacroux et al., 2008; Lasa et al., 2012; Verdenal et al., 2015; Dienes-Nagy et al., 2020). Therefore, combined foliar applications of both nitrogen and seaweed extracts may stimulate grapevine nitrogen metabolism and therefore the synthesis of amino acids, leading to stored nitrogen in source organs. This nitrogen can be transported to sink organs, such as young leaves and grapes (Verdenal et al., 2016; Gutiérrez-Gamboa et al., 2017a; Verdenal et al., 2020). In other studies, Frioni et al. (2018) and Salvi et al. (2019) observed that foliar applications of $A$. nosodum extracts to grapevines at a dosage of $3 \mathrm{~g} / \mathrm{L}$ and $1.5 \mathrm{~kg} / \mathrm{ha}$, respectively, increased skin anthocyanin accumulation and total phenolic content in berries. Frioni et al. (2019) demonstrated that this increase was related to the specific modulation of genes involved in the activation of metabolic pathways of flavonoid synthesis. These authors also showed that grapevines treated with an A. nodosum fertilizer were less affected by gray rot (Botrytis cinerea) compared to untreated grapevines. On the other hand, Taskos et al. (2019) observed that foliar applications of an A. nodosum extract at a concentration of $1 \%(\mathrm{v} / \mathrm{v})$ to 'Merlot' grapevines increased yield, cluster berry number, anthocyanin extraction capacity from berry skins and seed tannins, while decreasing grape total polyphenol index. Gutiérrez-Gamboa (2020) reported that seaweed foliar applications to 'Tempranillo Blanco' grapevines at $0.25 \%(\mathrm{v} / \mathrm{v})$ 
increased catechin and flavonol contents, regardless of the climatic conditions of the season, whereas the application of the seaweed at $0.50 \%(\mathrm{v} / \mathrm{v})$ to grapevines increased the concentration of several amino acids on a dry season compared to a wet one. Therefore, seaweeds can likely behave as elicitors and as such could trigger enzyme activity responsible for the synthesis of phenolic compounds in grapevine tissues in vineyards cultivated under different climatic conditions. On the other hand, Gutiérrez-Gamboa et al. (2020c) reported that a seaweed extract applied at $0.25 \%$ (v/v) to 'Tempranillo' grapevines increased the content of several amino acids compared to the application at $0.50 \%(\mathrm{v} / \mathrm{v})$ of the same extract on a dry season. In this way, Paladines-Quezada et al. (2019) indicated that the application of methyl jasmonate (abiotic elicitor) to grapevines caused significant changes in structural components of grape skin cell walls, such as phenolic compounds, proteins and sugars. In their report 'Monastrell' and 'Cabernet Sauvignon' cultivars showed a positive effect of the application while 'Merlot' exhibited an opposite one. These results suggest an important varietal dependence when an elicitor is applied to grapevines, probably due to the great variability in the structural components of the cell walls of the grape berries.

\section{Enzyme metabolism activation}

Only one study reported the enzymatic reactions that occur after commercial seaweed extracts were applied to grapevines (Frioni et al., 2019). They showed that the application of a seaweed extract did not affect the expression of flavonoid 3-Oglucosyltransferase (UFGT), flavonoid $O$-methyl transferase 2 (OMT2), leucocyanidin dioxygenase (LDOX), glutathione S-transferase (GST), flavonoid 3' hydroxylase (F3'H), flavonoid 3'5' hydroxylase $\left(\mathrm{F}^{\prime}{ }^{\prime} 5^{\prime} \mathrm{H}\right)$ or dihydroflavonol reductase (DFR) at full veraison stage. At the moment in which the grapes reached $19{ }^{\circ}$ Brix, seaweed applications enhanced UFGT, LDOX, GST, F3'H, F3'5'H and DFR transcription levels. At technological maturity, relative expression of UFGT, OMT2, LDOX, GST and F3'5'H was higher in non-treated grapevines (Frioni et al., 2019). Despite the interesting results shown by these authors, there was no clear relationship between the relative expression of genes and the accumulation of phenolic compounds or other secondary metabolites in grape berries. Therefore, the knowledge regarding the effects of algae foliar application to grapevines on the relative expression of genes involved in the synthesis of secondary metabolites in grapes is not yet fully understood.

\section{SHORT-TERM RESEARCH PERSPECTIVES}

Seaweed-based biostimulants may reduce the incidence and severity of grapevine diseases, improve yield and change grape and wine composition, as described above. However, the mechanisms of action involved in these processes are not fully understood. The knowledge of leaf surface wetting properties must be combined with the advance in the insights on their interactions with the physico-chemical properties of seaweed foliar formulations, including surfactants, with the aim to promote an optimal and prolonged use of the biostimulants applied, especially under hot, dry and cold weather conditions (Konlechner and Sauer, 2016). The contribution of the stomatal pathway to the foliar nutrient uptake process should be further studied as well as the role of other epidermal structures such as trichomes and lenticels (Fernández et al., 2014). Frioni et al. (2019) reported for the first time that seaweed applications to grapevines may modulate genes related to flavonoid pathways and the upregulation of some defense-related genes. The modulation of genes related to the accumulation of volatile compounds, such as terpenes, $\mathrm{C}_{13}$ norisoprenoids, benzenes, alcohols and carbonyl compounds could be investigated to elucidate the upregulation of other defense-related genes in grapevines that have not yet been considered in research studies. Cell walls of seaweeds are rich in sulfated polysaccharides, including carrageenan in red algae, ulvan in green algae and fucoidan in brown algae (Cunha and Grenha, 2016). Most of the studies on the application of seaweeds in viticulture have been carried out using the brown algae Ascophyllum nodosum, so other brown, green, red algae could be studied. Biological activity of seaweed cell wall polysaccharides strongly depends on their structural properties, such as degree of substitution, molecular weight, type of sugar and functional groups (Synytsya et al., 2010). Therefore, the knowledge of these functional and physicochemical characteristics is important to develop an optimized seaweed formulation in order to improve the solubilization and the retention of these products on the leaf surface.

\section{CONCLUDING REMARKS}

The use of seaweeds in viticulture has allowed to improve grapevine productivity and to enhance grape and wine quality, mostly in terms of their phenolic composition. Mechanisms of action of seaweed products applied to the grapevines have not been fully studied but this review provides an overview on their effects as elicitors and foliar fertilizers. Their effectiveness seems to be mainly associated to seasonal climatic conditions, to the species of seaweed applied, its structural properties, leaf surface wetting properties of the grapevine variety, the stress and resistance level of the grapevine prior to the application, dosage of the formulation and their implications on relative expression genes in leaves and berries. Upcoming 
studies must be carried out to understand these conditions in order to obtain specific formulations for each grapevine variety. Finally, despite that Vitis vinifera grapevine varieties possess defense mechanisms against elicitors, the biosynthesis of defense-related compounds and other active and passive mechanisms is too slow, and it may take from few hours to a few days to get activated. In addition, the grapevine defense capacities depend on the organs elicited such as leaves, inflorescences, grapes, among others, and the phenological stages in which elicitation occurred. Therefore, the induction of the grapevine natural defense mechanisms through seaweed commercial products application must be considered in the context of an integrated vineyard management approach.

\section{REFERENCES}

Adhikari S., Adhikari A., Weaver D.K., Bekkerman A., Menalled F.D., 2019. Impacts of agricultural management systems on biodiversity and ecosystem services in highly simplified dryland landscapes. Sustainability, 11, 3223.

Ale M.T., Mikkelsen J.D., Meyer A.S., 2012. Designed optimization of a single-step extraction of fucose-containing sulfated polysaccharides from Sargassum sp. J. Appl. Phycol., 24, 715-723.

Arioli T., Mattner S.W., Winberg P.C., 2015. Applications of seaweed extracts in Australian agriculture: past, present and future. J. Appl. Phycol., 27, 2007-2015.

Audibert L., Fauchon M., Blanc N., Hauchard D., Ar Gall E., 2010. Phenolic compounds in the brown seaweed Ascophyllum nodosum: distribution and radical-scavenging activities. Phytochem. Anal., 21, 399-405.

Aziz A., Poinssot B., Daire X., Adrian M., Bézier A., Lambert B., Joubert J.M., Pugin A., 2003. Laminarin elicits defense responses in grapevine and induces protection against Botrytis cinerea and Plasmopara viticola. Mol. Plant-Microbe Interact., 16, $1118-1128$

Balboa E.M., Conde E., Moure A., Falqué E., Domínguez H., 2013. In vitro antioxidant properties of crude extracts and compounds from brown algae. Food Chem., 138, 1764-1785.

Banerjee S., Walder F., Büchi L., Meyer M., Held A.Y., Gattinger A., Keller T., Charles R., van der Heijden M.G.A., 2019. Agricultural intensification reduces microbial network complexity and the abundance of keystone taxa in roots. ISME $J .$, 13, 1722-1736.

Battacharyya D., Babgohari M.Z., Rathor P., Prithiviraj B., 2015. Seaweed extracts as biostimulants in horticulture. Sci. Hortic., 196, 39-48.

Bigeard J., Colcombet J., Hirt H., 2015. Signaling mechanisms in pattern-triggered immunity (PTI). Mol. Plant., 8, 521-539.

Blunden G., Morse P.F., Mathe I., Hohmann J., Critchley A.T., Morrell S., 2010. Betaine yields from marine algal species utilized in the preparation of seaweed extracts used in agriculture. Nat. Prod. Commun., 5, 581-585.

Briceño-Domínguez D., Hernández-Carmona G., Moyo M., Stirk W., van Staden J., 2014. Plant growth promoting activity of seaweed liquid extracts produced from Macrocystis pyrifera under different $\mathrm{pH}$ and temperature conditions. J. Appl. Phycol., 26, 2203-2210.
Cheng X., Liang Y., Zhang A., Wang P., He S., Zhang K., Wang J., Fang Y., Sun X., 2020. Using foliar nitrogen application during veraison to improve the flavor components of grape and wine. J. Sci. Food Agric. (in press)

Chizhov A.O., Dell A., Morris H.R., Haslam S.M., McDowell R.A., Shashkov A.S., Nifant'ev N.E., Khatuntseva E.A., Usov A.I., 1999. A study of fucoidan from the brown seaweed Chorda filum. Carbohydr. Res., 320, 108-119.

Craigie J.S., 2011. Seaweed extract stimuli in plant science and agriculture. J. Appl. Phycol., 23, 371-393.

Cunha L., Grenha A., 2016. Sulfated seaweed polysaccharides as multifunctional materials in drug delivery applications. Mar. Drugs., 14, 42.

Delaunois B., Farace G., Jeandet P., Clément C., Baillieul F., Dorey S., Cordelier S., 2014. Elicitors as alternative strategy to pesticides in grapevine? Current knowledge on their mode of action from controlled conditions to vineyard. Environ. Sci. Pollut. Res., 21, 4837-4846.

Dienes-Nagy Á., Marti G., Breant L., Lorenzini F., Fuchsmann P., Baumgartner D., Zufferey V., Spring J.-L., Gindro K., Viret O., Wolfender J.-L., Rösti J., 2020. Identification of putative chemical markers in white wine (Chasselas) related to nitrogen deficiencies in vineyards. OENO One, 54, 583-599.

Echeverría G., Ferrer M., Mirás-Avalos J., 2017. Quantifying the relative impact of physical and human factors on the viticultural expression of terroir. Int. J. Environ. Agric. Res., 3, 12-25.

El Boukhari M.E.M., Barakate M., Bouhia Y., Lyamlouli K., 2020. Trends in seaweed extract based biostimulants: Manufacturing process and beneficial effect on soil-plant systems. Plants, 9, 359.

Fernández V., Bahamonde H.A., Peguero-Pina J.J., Gil-Pelegrín E., Sancho-Knapik D., Gil L., Goldbach H.E., Eichert T., 2017. Physico-chemical properties of plant cuticles and their functional and ecological significance. J. Exp. Bot., 68, 5293-5306.

Fernández V., Eichert T., 2009. Uptake of hydrophilic solutes through plant leaves: Current state of knowledge and perspectives of foliar fertilization. CRC. Crit. Rev. Plant Sci., 28, 36-68.

Fernández V., Guzmán-Delgado P., Graça J., Santos S., Gil L., 2016. Cuticle structure in relation to chemical composition: Reassessing the prevailing model. Front. Plant Sci., 7, 427.

Fernández V., Sancho-Knapik D., Guzmán P., Peguero-Pina J.J., Gil L., Karabourniotis G., Khayet M., Fasseas C., HerediaGuerrero J.A., Heredia A., Gil-Pelegrín E., 2014. Wettability, polarity, and water absorption of holm oak leaves: Effect of leaf side and age. Plant Physiol., 166, 168-180.

Fernández V., Sotiropoulos T., Brown P., 2013. Foliar fertilization scientific principles and field practices. $140 \mathrm{p}$. International Fertilizer Industry Association (IFA), Paris.

Fleurence J., 1999. Seaweed proteins: Biochemical, nutritional aspects and potential uses. Trends Food Sci. Technol., 10, 25-28.

Fleurence J., 2004. Seaweed proteins. In: Food Science, Technology and Nutrition. 197-213. Yada R.Y. (ed.), Woodhead Publishing Series in Food Science, Technology and Nutrition, Elsevier, Amsterdam.

Flórez-Fernández N., Torres M.D., González-Muñoz M.J., Domínguez H., 2018. Potential of intensification techniques for the extraction and depolymerization of fucoidan. Algal Res., 30, 128-148.

Fries N., 1979. Physiological characteristics of Mycosphaerella ascophylli, a fungal endophyte of the marine brown alga Ascophyllum nodosum. Physiol. Plant., 45, 117-121. 
Fries N., Thorén-Tolling K., 1978. Identity of the fungal endophyte of Ascophyllum wth Mycosphaerella ascophylli established by means of fluorescent antibody technique. Bot. Mar., 21, 409-412.

Frioni T., Sabbatini P., Tombesi S., Norrie J., Poni S., Gatti M., Palliotti A., 2018. Effects of a biostimulant derived from the brown seaweed Ascophyllum nodosum on ripening dynamics and fruit quality of grapevines. Sci. Hortic., 232, 97-106.

Frioni T., Tombesi S., Quaglia M., Calderini O., Moretti C., Poni S., Gatti M., Moncalvo A., Sabbatini P., Berrìos J.G., Palliotti A., 2019. Metabolic and transcriptional changes associated with the use of Ascophyllum nodosum extracts as tools to improve the quality of wine grapes (Vitis vinifera $\mathrm{cv}$. Sangiovese) and their tolerance to biotic stress. J. Sci. Food Agric., 99, 63506363.

Ganesan P., Kumar C.S., Bhaskar N., 2008. Antioxidant properties of methanol extract and its solvent fractions obtained from selected Indian red seaweeds. Bioresour. Technol., 99, 2717-2723.

Garbary D.J., Gautam A., 1989. The Ascophyllum, Polysiphonia, Mycosphaerella symbiosis I. Population ecology of Mycosphaerella from Nova Scotia. Bot. Mar., 32, 181-186.

Garde-Cerdán T., Mancini V., Carrasco-Quiroz M., Servili A., Gutiérrez-Gamboa G., Foglia R., Pérez-Álvarez E.P., Romanazzi G., 2017. Chitosan and laminarin as alternatives to copper for Plasmopara viticola control: Effect on grape amino acid. $J$. Agric. Food Chem., 65, 7379-7386.

Gauthier A., Trouvelot S., Kelloniemi J., Frettinger P., Wendehenne D., Daire X., Joubert J.-M., Ferrarini A., Delledonne M., Flors V., Poinssot B., 2014. The sulfated laminarin triggers a stress transcriptome before priming the SAand ROS-dependent defenses during grapevine's induced resistance against Plasmopara viticola. PLoS One, 9, e88145.

Godlewska K., Michalak I., Tuhy Ł., Chojnacka K., 2016. Plant growth biostimulants based on different methods of seaweed extraction with water. Biomed Res. Int., 5973760.

Gutiérrez-Gamboa G., 2020. Aplicación foliar en el viñedo de un extracto del alga Ascophyllum nodosum como herramienta para mejorar la composición nitrogenada, fenólica y aromática de la uva y del vino de las variedades Tempranillo y Tempranillo Blanco. 197 p. PhD Thesis, Universidad de La Rioja.

Gutiérrez-Gamboa G., Garde-Cerdán T., Carrasco-Quiroz M., Martínez-Gil A.M., Moreno-Simunovic Y., 2018. Improvement of wine volatile composition through foliar nitrogen applications to "Cabernet Sauvignon" grapevines in a warm climate. Chil. J. Agric. Res., 78, 216-227.

Gutiérrez-Gamboa G., Garde-Cerdán T., Gonzalo-Diago A., Moreno-Simunovic Y., Martínez-Gil A.M., 2017a. Effect of different foliar nitrogen applications on the must amino acids and glutathione composition in Cabernet Sauvignon vineyard. LWT - Food Sci. Technol., 75, 147-154.

Gutiérrez-Gamboa G., Garde-Cerdán T., Portu J., MorenoSimunovic Y., Martínez-Gil A.M., 2017b. Foliar nitrogen application in Cabernet Sauvignon vines: Effects on wine flavonoid and amino acid content. Food Res. Int., 96, 46-53.

Gutiérrez-Gamboa G., Garde-Cerdán T., Rubio-Bretón P., PérezÁlvarez E.P., 2020a. Study of must and wine amino acids composition after seaweed applications to Tempranillo blanco grapevines. Food Chem., 308, 125605.

Gutiérrez-Gamboa G., Garde-Cerdán T., Rubio-Bretón P., PérezÁlvarez E.P., 2020b. Seaweed foliar applications at two dosages to Tempranillo blanco (Vitis vinifera L.) grapevines in two seasons: Effects on grape and wine volatile composition. Food Res. Int., 130, 108918.
Gutiérrez-Gamboa G., Garde-Cerdán T., Rubio-Bretón P., PérezÁlvarez E.P., 2020c. Biostimulation to Tempranillo grapevines (Vitis vinifera $\mathrm{L}$.) through a brown seaweed during two seasons: Effects on grape juice and wine nitrogen compounds. Sci. Hortic., 264, 109177

Gutiérrez-Gamboa G., Garde-Cerdán T., Souza-Da Costa B., Moreno-Simunovic Y., 2019a. Strategies for the improvement of fruit set in Vitis vinifera L. cv. 'Carménère' through different foliar biostimulants in two different locations. Ciência Téc. Vitiv., 33, 177-183.

Gutiérrez-Gamboa G., Portu J., Santamaría P., López R., GardeCerdán T., 2017c. Effects on grape amino acid concentration through foliar application of three different elicitors. Food Res. Int., 99, 688-692.

Gutiérrez-Gamboa G., Verdugo-Vásquez N., Díaz-Gálvez I., 2019b. Influence of type of management and climatic conditions on productive behavior, oenological potential, and soil characteristics of a 'Cabernet Sauvignon' vineyard. Agronomy, 9, 64 .

Hammond-Kosack K.E., Jones J.D.G., 1996. Resistance genedependent plant defense responses. Plant Cell, 8, 1773-1791.

Hannah L., Roehrdanz P.R., Ikegami M., Shepard A. V., Shaw M.R., Tabor G., Zhi L., Marquet P.A., Hijmans R.J., 2013. Climate change, wine, and conservation. Proc. Natl. Acad. Sci. U. S. A., 110, 6907-6912

Howarth R.W., 2008. Coastal nitrogen pollution: A review of sources and trends globally and regionally. Harmful Algae, 8 , 14-20.

Jeong S.T., Goto-Yamamoto N., Kobayashi S., Esaka M., 2004. Effects of plant hormones and shading on the accumulation of anthocyanins and the expression of anthocyanin biosynthetic genes in grape berry skins. Plant Sci., 167, 247-252.

Jones G.V., Davis R.E., 2000. Climate Influences on grapevine phenology, grape composition, and wine production and quality for Bordeaux, France. Am. J. Enol. Vitic., 51, 249-261.

Kadam S.U., Tiwari B.K., O'Connell S., O’Donnell C.P., 2015a. Effect of ultrasound pretreatment on the extraction kinetics of bioactives from brown seaweed (Ascophyllum nodosum). Sep. Sci. Technol., 50, 670-675.

Kadam S.U., Tiwari B.K., Smyth T.J., O’Donnell C.P., 2015b. Optimization of ultrasound assisted extraction of bioactive components from brown seaweed Ascophyllum nodosum using response surface methodology. Ultrason. Sonochem., 23, 308316.

Keller M., 2020. The science of grapevines. Anatomy and physiology. 554 p. Academic Press, Cambridge.

Keyrouz R., Abasq M.L., Bourvellec C. Le, Blanc N., Audibert L., Argall E., Hauchard D., 2011. Total phenolic contents, radical scavenging and cyclic voltammetry of seaweeds from Brittany. Food Chem., 126, 831-836.

Khan A.S., Ahmad B., Jaskani M.J., Ahmad R., Malik A.U., 2012. Foliar application of mixture of amino acids and seaweed (Ascophylum nodosum) extract improve growth and physicochemical properties of grapes. Int. J. Agric. Biol., 14, 383-388.

Khan W., Rayirath U.P., Subramanian S., Jithesh M.N., Rayorath P., Hodges D.M., Critchley A.T., Craigie J.S., Norrie J., Prithiviraj B., 2009. Seaweed extracts as biostimulants of plant growth and development. J. Plant Growth Regul., 28, 386399.

Kirkwood R.C., 1999. Recent developments in our understanding of the plant cuticle as a barrier to the foliar uptake of pesticides. Pestic. Sci., 55, 69-77. 
Klarzynski O., Plesse B., Joubert J.M., Yvin J.C., Kopp M., Kloareg B., Fritig B., 2000. Linear $\beta-1,3$ glucans are elicitors of defense responses in tobacco. Plant Physiol., 124, 1027-1037.

Konlechner C., Sauer U., 2016. Ultrastructural leaf features of grapevine cultivars (Vitis vinifera L. ssp. vinifera). Oeno One, 50, 195-207.

Lacroux F., Tregoat O., Van Leeuwen C., Pons A., Tominaga T., Lavigne-Cruège V., Dubourdieu D., 2008. Effect of foliar nitrogen and sulphur application on aromatic expression of Vitis vinifera L. cv. Sauvignon blanc. J. Int. des Sci. la Vigne du Vin, 42, 125-132.

Lasa B., Menendez S., Sagastizabal K., Cervantes M.E.C., Irigoyen I., Muro J., Aparicio-Tejo P.M., Ariz I., 2012. Foliar application of urea to "Sauvignon Blanc" and "Merlot" vines: Doses and time of application. Plant Growth Regul., 67, 73-81.

Leece D., 1976. Composition and ultrastructure of leaf cuticles from fruit trees, relative to differential foliar absorption. Funct. Plant Biol., 3, 833.

Lemaître-Guillier C., Hovasse A., Schaeffer-Reiss C., Recorbet G., Poinssot B., Trouvelot S., Daire X., Adrian M., Héloir M.C., 2017. Proteomics towards the understanding of elicitor induced resistance of grapevine against downy mildew. J. Proteomics, 156, 113-125.

Liu P.L., Du, L., Huang Y., Gao S.M., Yu M., 2017. Origin and diversification of leucine-rich repeat receptor-like protein kinase (LRR-RLK) genes in plants. BMC Evol. Biol., 17, 1-16.

MacKinnon S.L., Hiltz D., Ugarte R., Craft C.A., 2010. Improved methods of analysis for betaines in Ascophyllum nodosum and its commercial seaweed extracts. J. Appl. Phycol., 22, 489-494.

Malik N.A.A., Kumar I.S., Nadarajah K., 2020. Elicitor and receptor molecules: Orchestrators of plant defense and immunity. Int. J. Mol. Sci., 21, 963.

Marone D., Russo M., Laidò G., De Leonardis A., Mastrangelo A., 2013. Plant nucleotide binding site-leucine-rich repeat (NBS-LRR) genes: Active guardians in host defense responses. Int. J. Mol. Sci., 14, 7302-7326.

Ménard R., Alban S., De Ruffray P., Jamois F., Franz G., Fritig B., Yvin J.C., Kauffmann S., 2004. $\beta$-1,3 glucan sulfate, but not $\beta-1,3$ glucan, induces the salicylic acid signaling pathway in tobacco and Arabidopsis. Plant Cell, 16, 3020-3032.

Mercier L., Lafitte C., Borderies G., Briand X., Esquerré-Tugayé M.T., Fournier J., 2001. The algal polysaccharide carrageenans can act as an elicitor of plant defence. New Phytol., 149, 43-51.

Mondello V., Larignon P., Armengol J., Kortekamp A., Vaczy K., Prezman F., Serrano E., Rego C., Mugnai L., Fontaine F., 2018. Management of grapevine trunk diseases: Knowledge transfer, current strategies and innovative strategies adopted in Europe. Phytopathol. Mediterr., 57, 369-383.

Nagahama T., Fujimoto K., Takami S., Kinugawa A., Narusuye K., 2009. Effective amino acid composition of seaweeds inducing food preference behaviors in Aplysia kurodai. Neurosci. Res., 64, 243-250.

Nakamura T., Nagayama K., Uchida K., Tanaka R., 1996. Antioxidant activity of phlorotannins isolated from the brown alga Eisenia bicyclis Fish. Sci., 62, 923-926.

Neset T.S., Wiréhn L., Klein N., Käyhkö J., Juhola S., 2019. Maladaptation in Nordic agriculture. Clim. Risk Manag., 23, 7887.

Nesler A., Perazzolli M., Puopolo G., Giovannini O., Elad Y., Pertot I., 2015. A complex protein derivative acts as biogenic elicitor of grapevine resistance against powdery mildew under field conditions. Front. Plant Sci., 6, 715.
Ngatia L., M. Grace III J., Moriasi D., Taylor R., 2019. Nitrogen and phosphorus eutrophication in marine ecosystems. In: Monitoring of Marine Pollution. 1-17. Fouzia H.B. (ed.), IntechOpen, London.

Nobel P.S., 2009. Physicochemical and Environmental Plant Physiology. 676 p. Elsevier, Amsterdam.

Norms R.F., Bukovac M.J., 1968. Structure of the pear leaf cuticle with special reference to cuticular penetration. Am. J. Bot., 55, 975-983.

Norrie J., Branson T., Keathley P.E., 2002. Marine plant extracts impact on grape yield and quality. Acta Hortic., 594, 315-319.

Okolie C.L., Mason B., Mohan A., Pitts N., Udenigwe C.C., 2019. The comparative influence of novel extraction technologies on in vitro prebiotic-inducing chemical properties of fucoidan extracts from Ascophyllum nodosum. Food Hydrocoll., 90, 462-471.

Paladines-Quezada D.F., Moreno-Olivares J.D., FernándezFernández, J.I., Bautista-Ortín, A.B., Gil-Muñoz, R., 2019. Influence of methyl jasmonate and benzothiadiazole on the composition of grape skin cell walls and wines. Food Chem., 277, 691-697.

Paris F., Trouvelot S., Jubien M., Lecollinet G., Joubert J.M., Chiltz A., Héloir M.C., Negrel J., Adrian M., Legentil L., Daire X., Ferrières V., 2019. Hydrophobized laminarans as new biocompatible anti-oomycete compounds for grapevine protection. Carbohydr. Polym., 225, 115224.

Parris K., 2011. Impact of agriculture on water pollution in OECD countries: Recent trends and future prospects. Int. J. Water Resour. Dev., 27, 33-52.

Pereira L., Morrison L., Shukla P.S., Critchley A.T., 2020. A concise review of the brown macroalga Ascophyllum nodosum (Linnaeus) Le Jolis. J. Appl. Phycol., 32, 3561-3584.

Peso-Echarri P., Frontela-Saseta C., González-Bermúdez C.A., Ros-Berruezo G.F., Martínez-Graciá C., 2012. Polisacáridos de algas como ingredientes funcionales en acuicultura marina: alginato, carragenato y ulvano. Rev. Biol. Mar. Oceanogr., 47, 373-381.

Popescu G.C., Popescu M., 2014. Effect of the brown alga Ascophyllum nodosum as biofertilizer on vegetative growth in grapevine (Vitis vinifera L.). Curr. Trends Nat. Sci., 3, 61-67.

Provost C., Pedneault K., 2016. The organic vineyard as a balanced ecosystem: Improved organic grape management and impacts on wine quality. Sci. Hortic., 208, 43-56.

Ramirez-Estrada K., Vidal-Limon H., Hidalgo D., Moyano E., Golenioswki M., Cusidó R., Palazon J., 2016. Elicitation, an effective strategy for the biotechnological production of bioactive high-added value compounds in plant cell factories. Molecules, 21, 182.

Ramsey R.J.L., Stephenson G.R., Hall J.C., 2005. A review of the effects of humidity, humectants, and surfactant composition on the absorption and efficacy of highly water-soluble herbicides. Pestic. Biochem. Physiol., 82, 162-175.

Rayirath P., Benkel B., Mark Hodges D., Allan-Wojtas P., MacKinnon S., Critchley A.T., Prithiviraj, B., 2009. Lipophilic components of the brown seaweed, Ascophyllum nodosum, enhance freezing tolerance in Arabidopsis thaliana. Planta, 230, 135-147.

Reed R.H., Davison I.R., Chudek J.A., Foster R., 1985. The osmotic role of mannitol in the Phaeophyta: an appraisal. Phycologia, 24, 35-47. 
Rogiers S.Y., Hardie W.J., Smith J.P., 2011. Stomatal density of grapevine leaves (Vitis vinifera L.) responds to soil temperature and atmospheric carbon dioxide. Aust. J. Grape Wine Res., 17, $147-152$

Romanazzi G., Mancini V., Feliziani E., Servili A., Endeshaw S., Neri D., 2016. Impact of alternative fungicides on grape downy mildew control and vine growth and development. Plant Dis., 100, 739-748.

Sabeena S.F., Alagarsamy S., Sattari Z., Al-Haddad S., Fakhraldeen S., Al-Ghunaim A., Al-Yamani F., 2020. Enzymeassisted extraction of bioactive compounds from brown seaweeds and characterization. J. Appl. Phycol., 32, 615-629.

Sabir A., 2015. Improvement of the pollen quality and germination levels in grapes (Vitis vinifera L.) by leaf pulverizations with nanosize calcite and seaweed extract (Ascophyllium nodosum). J. Anim. Plant Sci., 25, 1599-1605.

Sabir A., Yazar K., Sabir F., Kara Z., Yazici M.A., Goksu N., 2014. Vine growth, yield, berry quality attributes and leaf nutrient content of grapevines as influenced by seaweed extract (Ascophyllum nodosum) and nanosize fertilizer pulverizations. Sci. Hortic., 175, 1-8.

Saigne-Soulard C., Abdelli-Belhadj A., Télef-Micouleau M., Cluzet S., Bouscaut J., Corio-Costet M.F., Mérillon J.M., 2015. Oligosaccharides from Botrytis cinerea and elicitation of grapevine defense. In: Polysaccharides: Bioactivity and Biotechnology. 939-958. Ramawat, K., Mérillon, J.M. (eds.), Springer International Publishing, New York

Salvi L., Brunetti C., Cataldo E., Niccolai A., Centritto M., Ferrini F., Mattii G.B., 2019. Effects of Ascophyllum nodosum extract on Vitis vinifera: Consequences on plant physiology, grape quality and secondary metabolism. Plant Physiol. Biochem., 139, 21-32.

Saravana P.S., Cho Y.N., Woo H.C., Chun B.S., 2018. Green and efficient extraction of polysaccharides from brown seaweed by adding deep eutectic solvent in subcritical water hydrolysis. J. Clean. Prod., 198, 1474-1484.

Sharma H.S.S., Fleming C., Selby C., Rao J.R., Martin T., 2014. Plant biostimulants: A review on the processing of macroalgae and use of extracts for crop management to reduce abiotic and biotic stresses. J. Appl. Phycol., 26, 465-490.

Shibata T., Nagayama K., Tanaka R., Yamaguchi K., Nakamura T., 2003. Inhibitory effects of brown algal phlorotannins on secretory phospholipase A2s, lipoxygenases and cyclooxygenases. J. Appl. Phycol., 15, 61-66.

Shukla P.S., Mantin E.G., Adil M., Bajpai S., Critchley A.T., Prithiviraj B., 2019. Ascophyllum nodosum-based biostimulants: Sustainable applications in agriculture for the stimulation of plant growth, stress tolerance, and disease management. Front. Plant Sci., 10, 655

Stirk W.A., Arthur G.D., Lourens A.F., Novák O., Strnad M., van Staden J., 2004. Changes in cytokinin and auxin concentrations in seaweed concentrates when stored at an elevated temperature. J. Appl. Phycol., 16, 31-39.

Stirk W.A., Tarkowská D., Turečová V., Strnad M., van Staden J., 2014. Abscisic acid, gibberellins and brassinosteroids in Kelpak ${ }^{\circledR}$, a commercial seaweed extract made from Ecklonia maxima. J. Appl. Phycol., 26, 561-567.

Stirk W.A., van Staden J., 1996. Comparison of cytokinin- and auxin-like activity in some commercially used seaweed extracts. J. Appl. Phycol., 8, 503-508.

Strydom J., 2014. The effect of foliar potassium and seaweed products in combination with a leonardite fertigation product on Flame Seedless grape quality. S. Afr. J. Enol. Vitic., 35, 283-291.
Synytsya A., Kim W.J., Kim S.M., Pohl R., Synytsya A., Kvasnička F., Čopíková J., Il Park Y., 2010. Structure and antitumour activity of fucoidan isolated from sporophyll of Korean brown seaweed Undaria pinnatifida. Carbohydr. Polym., 81, 41-48.

Taskos D., Stamatiadis S., Yvin J.C., Jamois F., 2019. Effects of an Ascophyllum nodosum (L.) Le Jol. extract on grapevine yield and berry composition of a Merlot vineyard. Sci. Hortic., 250, 27-32.

Thankaraj S.R., Sekar V., Kumaradhass H.G., Perumal N., Hudson A.S., 2020. Exploring the antimicrobial properties of seaweeds against Plasmopara viticola (Berk. and M.A. Curtis) Berl. and De Toni and Uncinula necator (Schwein) Burrill causing downy mildew and powdery mildew of grapes. Indian Phytopathol., 73, 185-201.

Tomasi D., Jones G.V., Giust M., Lovat L., Gaiotti F., 2011. Grapevine phenology and climate change: Relationships and trends in the Veneto region of Italy for 1964-2009. Am. J. Enol. Vitic., 62, 329-339.

Turan M., Köse C., 2004. Seaweed extracts improve copper uptake of grapevine. Acta Agric. Scand. Sect. B Soil Plant Sci., 54, 213-220.

Vasconcelos M.C., Greven M., Winefield C.S., Trought M.C.T., Raw V., 2009. The flowering process of Vitis vinifera: A review. Am. J. Enol. Vitic., 60, 411-434.

Vásquez V., Martínez R., Bernal C., 2019. Enzyme-assisted extraction of proteins from the seaweeds Macrocystis pyrifera and Chondracanthus chamissoi: characterization of the extracts and their bioactive potential. J. Appl. Phycol., 31, 1999-2010.

Verdenal T., Spangenberg J.E., Zufferey V., Dienes-Nagy Á., Viret O., Van Leeuwen C., Spring J.L., 2020. Impact of crop load on nitrogen uptake and reserve mobilisation in Vitis vinifera. Funct. Plant Biol., 47, 744.

Verdenal T., Spangenberg J.E., Zufferey V., Lorenzini F., Dienes-Nagy A., Gindro K., Spring J.L., Viret O., 2016. Leaf-tofruit ratio affects the impact of foliar-applied nitrogen on $\mathrm{N}$ accumulation in the grape must. J. Int. des Sci. Vigne du Vin, 50, 23-33.

Verdenal T., Spangenberg J.E., Zufferey V., Lorenzini F., Spring J.-L., Viret O., 2015. Effect of fertilisation timing on the partitioning of foliar-applied nitrogen in Vitis vinifera cv. Chasselas: a ${ }^{15} \mathrm{~N}$ labelling approach. Aust. J. Grape Wine Res., 21, 110-117.

Verkleij F.N., 1992. Seaweed extracts in agriculture and horticulture: A review. Biol. Agric. Hortic., 8, 309-324.

Wang T., Jónsdóttir R., Ólafsdóttir G., 2009. Total phenolic compounds, radical scavenging and metal chelation of extracts from Icelandic seaweeds. Food Chem., 116, 240-248

Yabur R., Bashan Y., Hernández-Carmona G., 2007. Alginate from the macroalgae Sargassum sinicola as a novel source for microbial immobilization material in wastewater treatment and plant growth promotion. J. Appl. Phycol., 19, 43-53.

Youssouf L., Lallemand L., Giraud P., Soulé F., Bhaw-Luximon A., Meilhac O., D’Hellencourt C.L., Jhurry D., Couprie J., 2017. Ultrasound-assisted extraction and structural characterization by NMR of alginates and carrageenans from seaweeds. Carbohydr. Polym., 166, 55-63.

Zermeño-González A., Mendez-López G., Rodríguez-García E., Cadena-Zapata M., Cárdenas-Palomo J.O., Catalán-Valencia E.A., 2015. Biofertilización de vid en relación con fotosíntesis, rendimiento y calidad de frutos. Agrociencia, 49, 875-887.

Zhang S., Mersha Z., Vallad G.E., Huang C.H., 2016. Management of powdery mildew in squash by plant and alga extract biopesticides. Plant Pathol. J., 32, 528-536. 